\title{
USAHA PENINGKATAN PRODUKTIVITAS TANAMAN KAKAO DI DESA BANJARHARJO KECAMATAN KALIBAWANG KABUPATEN KULON PROGO
}

\author{
Oleh : \\ Isna Manistasari ${ }^{1}$ dan Nurhadi $^{2}$ \\ ${ }^{1}$ Pemerhati dan Pegiat Pendidikan Geografi \\ ${ }^{2}$ Jurusan Pendidikan Geografi, Universitas Negeri Yogyakarta
}

\begin{abstract}
Abstrak
Penelitian ini bertujuan untuk: (1) Mengidentifikasi faktor fisik dan non fisik yang mempengaruhi usaha tani kakao, (2) Mengidentifikasi faktor penyebab penurunan produktivitas tanaman kakao, (3) Mengkaji cara meningkatkan produktivitas tanaman kakao di Desa Banjarharjo. Penelitian ini termasuk penelitian deskriptif kuantitatif. Populasi dalam penelitian ini berjumlah 668 petani kakao yang tersebar di 16 Dusun. Sampel dalam penelitian ini diambil dengan cara area sampling. Teknik area sampling ini membagi suatu daerah besar ke dalam daerah-daerah kecil dan dibagi lagi menjadi daerah yang lebih kecil, sehingga didapat 40 sampel petani dari 4 Dusun yang mempunyai tanaman kakao lebih dari 7000 pohon sebagai responden. Pengumpulan data menggunakan metode observari, wawancara, dan dokumentasi. Teknik pengolahan data dalam penelitian ini yaitu editing, koding dan tabulasi. Analisis data menggunakan analisis deskriptif. Hasil penelitian menunjukkan bahwa: (1) Kondisi fisik dan non fisik yang mempengaruhi usaha tani kakao di daerah penelitian meliputi, kondisi iklim dan tanah di daerah penelitian sesuai dengan syarat tumbuh tanaman kakao. Kondisi non fisik yang berkaitan terhadap usahatani kakao di daerah penelitian adalah modal, tenaga kerja, transportasi, pemasaran, fasilitas kredit, serta teknologi. (2) Faktor penyebab penurunan produktivitas tanaman kakao adalah umur tanaman kakao yang sudah terlalu tua, adanya hama penyakit kakao, kekurangan air, kurangnya modal dan keterbatasan waktu pengelolaan tanaman kakao. (3) Usaha penigkatan produktivitas kakao meliputi usaha teknis dan non teknis, usaha teknis antara lain: pemilihan bibit ungul, sanitasi, pemetikan rutin, sambung samping, sarungisasi kakao. Sedangkan usaha non teknis antara lain: mengikuti penyuluhan, kelompok tani, mencari informasi tentang usaha tani kakao melalui buku maupun media masa.
\end{abstract}

Kata kunci: Usaha Tani, Peningkatan Kakao, Produktivitas

\section{THE EFFORTS OF IMPROVING THE PRODUCTIVITY OF COCOA IN BANJARHARJO VILLAGE, KALIBAWANG DISTRICT, KULON PROGO}

\footnotetext{
$\underline{\text { Abstract }}$

This research aims to: (1) identify physical and non-physical factors that influence cocoa farming, (2) identify the factors which cause the decline of cocoa trees productivity, (3) study how to improve the productivity of cocoa trees in the village of Banjarharjo. This research is a quantitative descriptive research. The population in this research consists of 668 cocoa farmers who spread in 16 Dusun (sub-village). The samples in this research were taken by using sampling area techniques. This technique divides a large area into smaller regions. Then, small regions were divided again into smaller regions. Therefore, there are 40 farmers as research respondents from 4 Dusun who have more than 7000
} 
cocoa trees. The data collection techniques consist of observations, interviews, and documentations. Moreover, the data analysis techniques in this research include editing, coding and tabulation. The data analysis was performed using descriptive analysis. The findings show that: (1) physical and non-physical conditions which influence cocoa farming in the research field, climate and soil, has supported for the growing cocoa trees. Non-physical conditions related to cocoa farming include capital, labor, transportation, marketing, credit facilities, and technology, (2) the factors which cause the decrease of cocoa productivity consist of cocoa age which is too old, the presence of cocoa pests, water shortages, lack of capital and time limitation for managing cocoa trees, (3) The efforts of improving cocoa productivity consist of technical and non-technical. Technical efforts include: selection of good seed, sanitation, routine picking, side grafting, and cocoa covering. Meanwhile, non-technical efforts include: joining trainings, farmer groups, and looking information about cocoa farming through books and media.

Keywords: Farming, Cacao Improvement, Productivity

\section{PENDAHULUAN}

Indonesia merupakan Negara agraris yang mana sebagian besar penduduknya bekerja dalam bidang pertanian. Pertanian mempunyai peranan yang penting bagi bangsa Indonesia. Pertanian merupakan pendapatan utama dan sumber devisa bagi Negara.

Pemerintah Indonesia, dalam hal ini departemen Pertanian, dalam rangka upaya meningkatkan pendapatan petani dan pendapatan Negara dari ekspor nonmigas, serta pengawetan kesuburan lahan pertanian, telah memulai mengembangkan usaha tanaman kakao. Pola pengembangan budidaya kakao, antara lain pola perkebunan Negara atau swasta, dan pola Perkebunan Inti Rakyat (PIR).

Tanaman kakao telah dikenal di Indonesia sejak tahun 1560, tetapi baru menjadi komoditi yang sangat penting sejak tahun 1951. Tanaman kakao tidak terlalu memilih-milih jenis tanah, jenis tanah yang paling sesuai untuk budidaya tanaman kakao agar hasilnya maksimal adalah pada tanah regosol.

Jenis yang pertama sekali ditanam di Indonesia Criollo, yaitu di daerah Sulawesi Utara yang berasal dari Venezuela. Pada tahun 1888 diperkenalkan jenis tanaman Java Criollo asal Venezuela yang berasal dari Sulawesi Utara, sebagai jenis tanaman tertua untuk mendapatkan bibit tanaman unggul. Sebelumnya pada tahun 1880, juga diperkenalkan jenis tanaman forestero asal Venezeula untuk maksud yang sama. Sejalan dengan itu, pengembangan pertanaman kakao di Indonesia, khususnya di Jawa, berjalan dengan pesat.Perkembangannya juga didorong oleh meluasnya penyakit kopi oleh Hemeleia vastatrix, yang mudah menyerang. (www.depperin.go.id/PaketInformasi/Kakao/kakao.pdf).

Indonesia sebenarnya berpotensi untuk menjadi produsen utama kakao dunia, apabila berbagai permasalahan utama yang dihadapi perkebunan kakao dapat diatasi dan agribisnis kakao dikembangkan dan dikelola secara baik.Harga kakao dunia yang relatif stabil dan cukup tinggi kakao perlu dibangun agar dapat memberikan produktivitas yang tinggi.Harga jual kakao yang cukup tinggi dan pemasaran yang mudah, lebih menguntungkan dibandingkan hasil pertanian yang biasa dibudidayakan 
oleh petani-petani setempat sebelumnya seperti pisang, ketela dan cengkih seperti yang dilakukan oleh masyarakat di Desa Banjarharjo.

Desa Banjarharjo sebagian besar merupakan dataran tinggi di daerah Pegunungan Menoreh dengan lingkup masyarakat desa yang sebagian besar mempunyai mata pencaharian sebagai petani padi, selain itu masyarakat juga menjadi petani kakao. Masyarakat mulai membudidayakan tanaman kakao sebagai sumber pendapatan tambahan sejak 20 tahun, yang mana selama ini pengelolaanya masih sederhana.

Pengembangan budidaya kakao masih mengalami beberapa kendala, antara lain; adanya tupai, jamur kakao membuat tanaman kakao busuk sebelum matang, serta pengelolaan tanaman kakao yang masih tradisional karena keterbatasan pengetahuan masyarakat. Masalah yang paling terlihat di Desa Banjarhajo yaitu menurunya produktivitas tanaman kakao sehingga pendapatan petani menurun drastis. Petani hanya bisa memanen maksimal sebulanhanya satu kali bahkan tidak ada sama sekali.

Keadaan ini berlangsung hampir setahun terakhir.Banyak petani membiarkanya begitu saja dan beberapa menebang tanaman kakao mereka. Banyaknya tanaman kakao yang tidak produktif kemungkinan besar karena umur tanaman kakao yang sudah terlalu tua serta musim yang tidak menentu,sehingga menyebabkan petani kakao enggan untuk menanam tanaman kakao lagi. Petani mengganti tanaman kakao dengan tanaman lain, seperti pisang, rambutan maupun ketela, namun pemerintah daerah tidak segera menangani masalah tersebut.

\section{METODE PENELITIAN}

Penelitian ini merupakan penelitian deskriptif kuantitatif yaitu berusaha mendeskripsikan segala sesuatu yang ada di lapangan yang berhubungan dengan usaha peningkatan produktivitas tanaman kakao di Desa Banjarharjo Kecamatan Kalibawang Kabupaten Kulonprogo. Penelitian ini dilakukan di Desa Banjarharjo Kecamatan Kalibawang Kabupaten Kulonprogo pada bulan Oktober 2011 sampai selesai.

Variabel dalampenelitian ini meliputi faktor fisik dan non fisik yang mendukung usaha tani kakao, Pengelolaan tanaman kakao, Produktivitas tanaman kakao, Kendala dalam pemeliharaan tanaman kakao, Cara mengatasi masalah dalam pengelolaan tanaman kakao, Usaha meningkatkan produktifitas tanaman kakao.

Populasi disini adalah semua petani kakao yang berada di Desa Banjarharjo. Desa Banjarharjo memiliki 668 petani kakao yang terdiri dari enam belas dusun. Sampel dalam penelitian ini diambil dengan cara area sampling. Area sampling ini membagi suatu daerah besar ke dalam daerah- daerah kecil dan daerah-daerah kecil ini pada gilirannya dibagi lagi menjadi daerah yang lebih kecil, (Sutrisno Hadi, 2004:188), kemudian dipilih empat dusun sebagai tempat penelitian.

Pemilihan empat dusun ini sebagai tempat Penelitian berdasarkan jumlah tanaman kakao yang lebih banyak dari pada Dusun lainnya yakni lebih dari 7000 pohon. Empat dusun yang terpilih tersebut yaitu Dusun Padakan Ngasem, Gerpule, Demangan dan Srandu. Masing-masing Dusun diambil sampel 10 petani kakao maka jumlah sampel adalah 40 responden, hal ini dikarenakan petani kakao yang homogen sehingga jumlah sampel tersebut dapat mewakili seluruh petani kakao di Desa Banjarharjo.

Data yang diambil dalam penelitian ini meliputi data primer dan data sekunder. Penelitian ini teknik pengumpulan data menggunakan: 
1. Observasi

Menurut Sutrisno Hadi (2004: 135), observasi adalah metode pengumpulan data dengan mengamati dan mencatat secara sistematis terhadap fenomenafenomena yang diteliti. Observasi yang dimaksudkan adalah tentang budidaya tanaman kakao.

2. Wawancara

Data yang diperoleh dari wawancara ini meliputi identitas responden, cara bercocok tanam kakao, luas lahan, tingkat produktivitas hasil usaha tani kakao, kendala serta cara mengatasi masalah dalam budidaya tanaman kakao.

3. Dokumentasi

Dokumentasi adalah metode pengumpulan data yang digunakan untuk mencatat data sekunder. Data sekunder ini diperoleh dengan cara mencatat tentang data penelitian di lembaga-lembaga pemerintah seperti: Kantor Kelurahan, Kantor Kecamatan, Dinas Pertanian, Bappeda. Data yang diperoleh antara lain: letak, luas, batas administrasi daerah penelitian, keadaan fisik, keadaan penduduk daerah penelitian.

Teknik analisis data untuk mengidentifikasi faktor pendukung dan penghambat usaha tani kakao di Desa Banjarharjo adalah analisis deskriptif kuantitatif. Analisa data dalam penelitian ini menggunakan tabel frekuensi. Tabel frekuensi digunakan untuk mengetahui pengelolaan kakao, pendapatan petani, jumlah produksi kakao dan cara meningkatkan produktivitas kakao.

\section{HASIL PENELITIAN DAN PEMBAHASAN}

Kondisi Fisik yang Mempengaruhi Usaha tani Kakao di Daerah Penelitian

Untuk mengetahui kesesuaian lahan untuk usaha tani kakao didaerah penelitian dapat dilihat pada Tabel 1 berikut ini:

Tabel 1. Kesesuaian lahan usaha tani kakao di Desa Banjarharjo

\begin{tabular}{|c|c|c|c|c|}
\hline No & $\begin{array}{c}\text { Faktor yang } \\
\text { Diamati }\end{array}$ & $\begin{array}{c}\text { Kondisi Daerah } \\
\text { Penelitian }\end{array}$ & $\begin{array}{c}\text { Syarat Tumbuh } \\
\text { Kakao }\end{array}$ & $\begin{array}{c}\text { Kondisi } \\
\text { Lahan }\end{array}$ \\
\hline 1. & Iklim & Suhu $25^{\circ} \mathrm{C}$ & $24^{\circ} \mathrm{C}-28^{\circ} \mathrm{C}$ & Sesuai \\
\hline 2. & Curah Hujan & $2228,1 \mathrm{~mm} /$ tahun & $\begin{array}{c}1.600-3.000 \\
\mathrm{~mm}\end{array}$ & Sesuai \\
\hline 3. & $\begin{array}{c}\text { Tanah } \\
\text { Jenis tanah }\end{array}$ & Latosol & $\begin{array}{c}\text { Latosol, podsolik } \\
\text { merah-kuning dan } \\
\text { andosol }\end{array}$ & Sesuai \\
\hline 4. & Drainase & Drainase baik & $\begin{array}{c}\text { Drainase agak } \\
\text { buruk - baik }\end{array}$ & Sesuai \\
\hline 5. & Ketinggian & $200-400 \mathrm{~m}$ dpal & $1-600 \mathrm{~m}$ dpal & Sesuai \\
\hline 6. & $\mathrm{pH}$ & $5,5-7$ & $5,6-6,8$ & Sesuai \\
\hline
\end{tabular}

Sumber: Data primer 2011

Faktor Non fisik

1. Modal

a. Kepemilikan lahan pertanian dan jumlah tanaman kakao 
Luas lahan pertanian yang digunakan untuk usaha tani kakao dapat dilihat pada Tabel 2 di bawah ini:

Tabel 2. Jumlah Luas Kepemilikan Lahan dan Tanaman Kakao

\begin{tabular}{|c|c|c|c|c|c|c|c|}
\hline $\begin{array}{l}\text { Jumlah tanaman } \\
\text { kakao } \\
\text { Luas kepemilikan } \\
\text { lahan } / \mathrm{m}^{2}\end{array}$ & $\begin{array}{l}\stackrel{\circ}{N} \\
v\end{array}$ & $\begin{array}{c}8 \\
\text { นn } \\
1 \\
\text { மี } \\
\text { N }\end{array}$ & $\begin{array}{c}\text { 우 } \\
\text { N } \\
1 \\
\text { 면 }\end{array}$ & 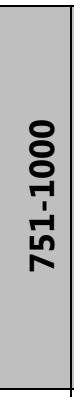 & $\begin{array}{c}8 \\
0 \\
-1 \\
\wedge\end{array}$ & $\mathbf{F}$ &  \\
\hline$<1000$ & 10 & 16 & 0 & 0 & 0 & 26 & 65 \\
\hline $1000-3000$ & 0 & 1 & 0 & 6 & 0 & 7 & 17,5 \\
\hline $3000-5000$ & 1 & 0 & 3 & 0 & 0 & 4 & 10 \\
\hline $5000-7000$ & 2 & 0 & 0 & 0 & 0 & 2 & 5 \\
\hline $7000-9000$ & 0 & 0 & 0 & 0 & 1 & 1 & 2,5 \\
\hline$>9000$ & 0 & 0 & 0 & 0 & 0 & 0 & 0 \\
\hline Jumlah & 13 & 17 & 4 & 6 & 0 & 40 & 100 \\
\hline
\end{tabular}

Sumber : Data Primer 2011

Berdasarkan Tabel 2 di atas diketahui diketahui sebanyak 26 responden (65\%) mengelola lahan pertanian kakao kurang dari $1000 \mathrm{~m}^{2}$ Kebanyakan petani menanam tanaman kakao di kebun maupun pekarangan.

b. Status Kepemilikan Lahan

Berdasarkan penelitian diketahui bahwa lahan yang digunakan semua responden melaksanakan usaha tani kakao adalah lahan milik sendiri.

c. Modal

Besar modal awal yang dikeluarkan para petani kakao dapat dilihat pada Tabel 3 berikut:

Tabel 3. Modal Awal Usaha tani Kakao per $1000 \mathbf{~ m}^{2}$

\begin{tabular}{|c|c|c|}
\hline Modal Awal & Frekuensi & Persentase \\
\hline$<$ Rp500.000 & 21 & 52,5 \\
\hline Rp 500.000-Rp 1000.000 & 14 & 35 \\
\hline $\operatorname{Rp~1000.000-Rp~1500.000~}$ & 3 & 7,5 \\
\hline$>$ Rp 2000.000 & 2 & 5 \\
\hline Jumlah & $\mathbf{4 0}$ & $\mathbf{1 0 0}$ \\
\hline
\end{tabular}

Sumber : Data Primer 2011

Berdasarkan Tabel 3 di atas dapat diketahui bahwa untuk melakukan usahatani kakao, sebagian besar petani yaitu $52,5 \%$ membutuhkan modal awal kurang dari Rp 500.000,00 per $1000 \mathrm{~m}^{2}$.

d. Asal modal

Asal modal petani kakao di Desa Banjarharjo dilihat pada Tabel 4 berikut: 
Tabel 4 . Asal Modal Untuk Usaha Tani Kakao

\begin{tabular}{|c|c|c|}
\hline Asal Modal & Frekuensi & Persentase \\
\hline Tidak mengeluarkan Modal & 12 & 30 \\
\hline Modal sendiri & 28 & 70 \\
\hline Jumlah & $\mathbf{4 0}$ & $\mathbf{1 0 0}$ \\
\hline
\end{tabular}

Sumber : Data Primer 2011

Berdasarkan Tabel 4 dapat diketahui bahwa sebagian besar petani yaitu 70\% mengeluarkan modal sendiri yaitu untuk biaya pengelolaan kakao, sedangkan hanya $30 \%$ yang tidak mengeluarkan modal.

2. Jumlah Tenaga Kerja

Jumlah tenaga kerja yang ikut dalam pengelolaan kakao dilihat pada Tabel 5.

Tabel 5. Jumlah tenaga kerja Per 1000 m² $^{2}$

\begin{tabular}{|c|c|c|}
\hline Jumlah Tenaga Kerja (Orang) & Frekuensi & Persentase \\
\hline 1 & 35 & 87,5 \\
\hline 2 & 4 & 10 \\
\hline$>2$ & 1 & 2,5 \\
\hline Jumlah & $\mathbf{4 0}$ & $\mathbf{1 0 0}$ \\
\hline
\end{tabular}

Sumber : Data Primer 2011

Berdasarkan Tabel 5 dapat diketahui bahwa sebagian besar petani yaitu $87,5 \%$ melakukan pengelolaan usahatani kakao sendiri, karena lahan pertaniannya tidak begitu luas sehingga mampu dikerjakan sendiri.

3. Pemasaran

Petani kakao melakukan pemasaran kakao seperti pada Tabel 6 berikut:

Tabel 6. Pemasaran Hasil Usaha tani Kakao

\begin{tabular}{|c|c|c|}
\hline Pemasaran & Frekuensi & Persentase \\
\hline Koperasi & 31 & 77,5 \\
\hline Pasar & 5 & 12,5 \\
\hline Warung/Tengkulak & 4 & 10 \\
\hline Jumlah & $\mathbf{4 0}$ & $\mathbf{1 0 0}$ \\
\hline
\end{tabular}

Sumber : Data Primer 2011

Berdasarkan Tabel 6 di atas dapat diketahuisebagian besar petani yaitu 77,5 \% menjual hasil panen kakao ke koperasi desa yang telah bekerjasama dengan PT Pagelaran, selain itu petani juga menjual hasil panennya ke pasar dan tengkulak.

4. Transportasi

Jenis transportasi yang digunakan responden dapat dilihat pada tabel 7:

Tabel 7. Jenis Transportasi Untuk Memasarkan Panen Kakao

\begin{tabular}{|c|c|c|}
\hline Pemasaran & Frekuensi & Persentase \\
\hline Angkutan umum & 2 & 5 \\
\hline Sepeda & 3 & 7,5 \\
\hline Sepeda motor & 13 & 32,5 \\
\hline Jalan kaki & 22 & 55 \\
\hline Jumlah & $\mathbf{4 0}$ & $\mathbf{1 0 0}$ \\
\hline
\end{tabular}


Sumber : Data Primer 2011

Berdasarkan Tabel 7 diatas diketahui bahwa sebagian besar masyarakat yaitu $55 \%$ responden masih berjalan kaki dalam memasarkan panen kakao karena jarak koperasi yang dekat kurang dari 1 $\mathrm{km}$ dan $32,5 \%$ responden menggunakan alat transportasi sepeda motor.

5. Layanan Kredit

Berdasarkan penelitian diperoleh data bahwa sebagian besar petani dalam usahatani kakao belum menggunakan fasilitas kredit.

6. Teknologi

Teknologi berkaitan dengan pengetahuan yang diperoleh petani. Sumber informasi pengetahuan petani dalam usaha tani kakao dapat dilihat pada Tabel 8 berikut:

Tabel 8. Sumber Informasi Mengenai Usaha Tani Kakao

\begin{tabular}{|c|c|c|}
\hline Sumber Informasi & Frekuensi & Persentase \\
\hline $\begin{array}{c}\text { Lembaga } \\
\text { formal/Penyuluhan }\end{array}$ & 34 & 85 \\
\hline Belajar sendiri & 4 & 10 \\
\hline Tukar wawasan & 2 & 5 \\
\hline Jumlah & $\mathbf{4 0}$ & $\mathbf{1 0 0}$ \\
\hline
\end{tabular}

Sumber : Data Primer 2011

Berdasarkan Tabel 8 diatas dapat diketahui bahwa 85\% dari jumlah responden mendapat informasi mengenai kakao dari penyuluhan- penyuluhan oleh PT Pagelaran. Penyuluhan dari KKN (Kuliah Kerja Nyata) juga dapat menambah pengetahuan tentang usaha tani kakao.

a. Pengelolaan tanaman kakao

1) Pembibitan tanaman kakao

Asal bibit kakao yang ditanam oleh petani kakao di Desa Banjarharjo dapat dilihat pada Tabel 9 di bawah ini:

Tabel 9. Asal Bibit Kakao

\begin{tabular}{|c|c|c|}
\hline Sumber Informasi & Frekuensi & Persentase \\
\hline Bantuan pemerintah & 38 & 95 \\
\hline Membeli sendiri & 2 & 5 \\
\hline Jumlah & $\mathbf{4 0}$ & $\mathbf{1 0 0}$ \\
\hline
\end{tabular}

Sumber : Data Primer 2011

Berdasarkan Tabel 9 diatas dapat diketahui bahwa sebagian besar bibit kakao dari bantuan pemerintah yaitu sebanyak 95\% yang diberikan melalui Dinas Perkebunan bekerjasama dengan PT Pagelaran memberikan bantuan bibit kakao kepada petani.

2) Persiapan Lahan Tanaman Kakao

a) Persiapan Lahan

Petani melaksanakan persiapan lahan atau tidak dapat diketahui dengan menanyakan kepada petani kakao. Berdasarkan penelitian dapat diketahui bahwa sebagian besar responden 100\% melakukan persiapan lahan 
sebelum melakukan penanaman kakao.

b) Pohon Penaung

Pohon penaung yang diberikan petani pada tanaman kakao dapat dilihat pada Tabel 10 berikut:

Tabel 10. Penggunaan Pohon Penaung

\begin{tabular}{|c|c|c|}
\hline Penggunaan pohon penaung & Frekuensi & Persentase \\
\hline Menggunakan pohon penaung & 37 & 92,5 \\
\hline $\begin{array}{c}\text { Tidak menggunakan pohon } \\
\text { Penaung }\end{array}$ & 3 & 7,5 \\
\hline Jumlah & $\mathbf{4 0}$ & $\mathbf{1 0 0}$ \\
\hline
\end{tabular}

Sumber : Data Primer 2011

Berdasarkan Tabel 10 diatas dapat diketahui bahwa sebagian besar responden yaitu $92,5 \%$ memberikan pohon penaung pada tanaman kakao mereka.

c) Penanaman

Berdasarkan penelitian dapat diketahui bahwa semua responden melaksanakan penanaman bibit kakao pada awal musim hujan yaitu antara antara bulan Oktober sampai bulan Februari.

d) Penyulaman tanaman kakao

Upaya petani kakao dalam melakukan penyulaman dapat dilihat pada Tabel 11 berikut ini:

Tabel 11. Penyulaman Kakao

\begin{tabular}{|c|c|c|}
\hline Upaya Penyulaman & Frekuensi & Persentase \\
\hline Melakukan penyulaman & 6 & 15 \\
\hline Tidak melakukan & 34 & 85 \\
\hline Jumlah & $\mathbf{4 0}$ & $\mathbf{1 0 0}$ \\
\hline
\end{tabular}

Sumber : Data Primer 2011

Berdasarkan Tabel 11 diatas dapat dilihat bahwa 85\% responden belum melakukan penyulaman karena petani belum mengetahui akan pentingnya penyulaman.

e) Penyiangan

Penyiangan yang dilakukan oleh petani kakao dapat dilihat pada Tabel 12 berikut ini:

Tabel 12. Penyiangan Kakao

\begin{tabular}{|c|c|c|}
\hline Upaya Penyulaman & Frekuensi & Persentase \\
\hline Melakukan penyiangan & 27 & 67,5 \\
\hline Tidak melakukan & 13 & 32,5 \\
\hline Jumlah & $\mathbf{4 0}$ & $\mathbf{1 0 0}$ \\
\hline
\end{tabular}

Sumber : Data Primer 2011

Berdasarkan Tabel 12 tersebut dapat dilihat bahwa sebagian besar masyarakat sudah melakukan penyiangan yaitu sebanyak $67,5 \%$ responden.

f) Pemupukan

a) Pelaksanaan Pemupukan

Berdasarkan penelitian dilapangan semua petani kakao melaksanakan 
pemupukan.

b) Jenis Pupuk

Tabel 13. Jenis Pupuk yang Digunakan Responden

\begin{tabular}{|c|c|c|}
\hline Jenis Pupuk & Frekuensi & Persentase \\
\hline Organik/Pupuk kandang & 23 & 57,5 \\
\hline Anorganik/Pupuk Kimia & 4 & 10 \\
\hline Organik dan Anorganik & 13 & 32,5 \\
\hline Jumlah & $\mathbf{4 0}$ & $\mathbf{1 0 0}$ \\
\hline
\end{tabular}

Sumber : Data Primer 2011

Berdasarkan Tabel 13 diatas dapat diketahui bahwa sebagian besar responden yaitu 57,5\% memupuk tanaman kakaonya menggunakan pupuk kandang karena para petani banyak yang mempunyai hewan ternak.

c) Dosis Pemupukan

Dosis pemupukan yang dilakukan oleh responden dapat dilihat pada

Tabel 14 berikut:

Tabel 14. Dosis Pemupukan Kakao di Desa Banjarharjo/th/batang

\begin{tabular}{|c|c|c|c|c|}
\hline \multirow{2}{*}{$\begin{array}{c}\text { Dosis Pupuk } \\
\text { (kg) }\end{array}$} & \multicolumn{2}{|c|}{ Anorganik } & \multicolumn{2}{c|}{ Organik } \\
\cline { 2 - 5 } & $\mathbf{F}$ & $\mathbf{\%}$ & $\mathbf{F}$ & $\mathbf{\%}$ \\
\hline$<0,5$ & 4 & 10 & 12 & 30 \\
\hline 0,5 & 2 & 5 & 13 & 32,5 \\
\hline$>0,5$ & 1 & 2,5 & 8 & 20 \\
\hline Jumlah & $\mathbf{7}$ & $\mathbf{1 7 , 5}$ & $\mathbf{3 3}$ & $\mathbf{8 2 , 5}$ \\
\hline
\end{tabular}

Sumber : Data Primer 2011

Berdasarkan Tabel 14 dapat diketahui sebanyak 32,5\% responden melaksanakan pemupukan menggunakan pupuk organik dengan dosis pemupukan $0,5 \mathrm{~kg} /$ tahun/batang.

g) Pengairan

Petani melaksanakan pengairan atau tidak dapat dilihat pada Tabel 15 berikut:

Tabel 15. Pelaksanaan pengairan

\begin{tabular}{|c|c|c|}
\hline $\begin{array}{c}\text { Pelaksanaan } \\
\text { Pengairan }\end{array}$ & Frekuensi & Persentase \\
\hline Melakukan & 15 & 37,5 \\
\hline Tidak melakukan & 25 & 62,5 \\
\hline Jumlah & $\mathbf{4 0}$ & $\mathbf{1 0 0}$ \\
\hline
\end{tabular}

Sumber : Data Primer 2011

Berdasarkan Tabel 15 di atas dapat diketahui bahwa 62,5\% responden tidak melakukan pengairan pada tanaman kakao.

h) Pemangkasan

Berdasarkan penelitian dapat diketahui bahwa semua petani yaitu $100 \%$ dari jumlah responden melaksanakan pemangkasan.

i) Panen Kakao

d) Panen Biji Kakao

Frekuensi pemanenan yang dilaksanakan responden dapat dilihat pada 
Tabel 16:

Tabel 16. Frekuensi Pemanenan tahun 2009 dan 2011

\begin{tabular}{|c|c|c|c|c|}
\hline Frekuensi Pemanenan/bln & $\mathbf{2 0 0 9}$ & \% & $\mathbf{2 0 1 1}$ & $\%$ \\
\hline$<2$ kali pemanenan/bln & 5 & 12,5 & 3 & 7,5 \\
\hline 2-3 kali pemanenan/bln & 11 & 27,5 & 1 & 2,5 \\
\hline 3-4 kali pemanenan/bln & 24 & 60 & 1 & 2,5 \\
\hline Tidak panen & - & 0 & 35 & 87,5 \\
\hline Jumlah & $\mathbf{4 0}$ & $\mathbf{1 0 0}$ & $\mathbf{4 0}$ & $\mathbf{1 0 0}$ \\
\hline
\end{tabular}

Sumber : Data Primer 2011

Berdasarkan Tabel 16 diatas, dapat diketahui pada tahun 2009 sebanyak $60 \%$ responden melakukan pemanenan kakao 3-4 kali pemanenan perbulan, sedangkan tahun 2011 sebanyak 87,5 \% responden menyatakan tidak dapat memanen tanaman kakaonya lagi karena umur kakao yang sudah terlalu tua.

b. Produktivitas tanaman kakao

1) Produktivitas Kakao dalam Satu Tahun

Perbandingan produktivitas kakao di Desa Banjarharjo pada tahun 2009 dan 2011 dapat dilihat pada Tabel 17 berikut:

Tabel 17. Perbandingan Produktivitas Kakao Dalam Satu Tahun, pada Tahun 2009 dan 2011

\begin{tabular}{|c|c|c|c|c|}
\hline Pendapatan/Th/1000 $\mathbf{~ m}^{\mathbf{2}}$ & $\mathbf{2 0 0 9}$ & $\mathbf{\%}$ & $\mathbf{2 0 1 1}$ & $\mathbf{\%}$ \\
\hline Tidak ada & 0 & 0 & 35 & 87,5 \\
\hline$<1.000 .000$ & 3 & 7,5 & 3 & 7,5 \\
\hline $1000.000-2000.000$ & 7 & 17,5 & 2 & 5 \\
\hline $2000.001-3000.000$ & 5 & 12,5 & 0 & 0 \\
\hline $3000.001-4000.000$ & 14 & 35 & 0 & 0 \\
\hline$>4000.000$ & 11 & 27,5 & 0 & 0 \\
\hline Jumlah & $\mathbf{4 0}$ & $\mathbf{1 0 0}$ & $\mathbf{4 0}$ & $\mathbf{1 0 0}$ \\
\hline
\end{tabular}

Sumber : Data Primer 2011

Berdasarkan Tabel 17 diatas menunjukkan bahwa pada tahun 2009 sebanyak 55\% petani kakao dapat memanen 51-100 kg/1000 malam $\mathrm{m}^{2}$ satu tahun sedangkan pada tahun 2011 , sebesar $12,5 \%$ hanya dapat memanen kurang dari $50 \mathrm{~kg} / 1000 \mathrm{~m}^{2}$.

2) Pendapatan Petani kakao Dalam Satu Tahun

Perbandingan pendapatan petani dalam satu tahun pada tahun 2009 dan 2011 dapat dilihat pada Tabel 18 berikut:

Tabel 18. Perbandingan pendapatan petani dalam satu tahun pada tahun 2009 dan 2011

\begin{tabular}{|c|c|c|c|c|}
\hline Produksi $\left(\mathbf{k g} / \mathbf{1 0 0 0} \mathbf{~ m}^{\mathbf{2}}\right)$ & $\mathbf{2 0 0 9}$ & $\mathbf{\%}$ & $\mathbf{2 0 1 1}$ & $\mathbf{\%}$ \\
\hline Tidak panen & 0 & 0 & 35 & 87,5 \\
\hline$<50$ & 18 & 45 & 5 & 12,5 \\
\hline
\end{tabular}




\begin{tabular}{|c|c|c|c|c|}
\hline $51-100$ & 22 & 55 & 0 & 0 \\
\hline Jumlah & $\mathbf{4 0}$ & $\mathbf{1 0 0}$ & $\mathbf{4 0}$ & $\mathbf{1 0 0}$ \\
\hline
\end{tabular}

Sumber : Data Primer 2011

Berdasarkan Tabel 18 diatas menunjukkan bahwa pada tahun 2009 sebanyak $27,5 \%$ petani kakao dapat memperoleh pendapatan sebesar Rp3.000.001,00-Rp4.000.000,00 per tahun $/ 1000 \mathrm{~m}^{2}$ dalam satu tahun sedangkan pada tahun 2011, hanya sebesar 7,5\% yang dapat memperoleh pendapatan kurang dari Rp.1.000.000,00

c. Hambatan dalam pengelolaan tanaman kakao

1) Tanaman kakao tidak berproduksi lagi

Hambatan tanaman kakao yang tidak berproduksi lagi dapat dilihat pada Tabel 19 berikut ini:

Tabel 19. Tanaman kakao tidak produktiv di Desa Banjarharjo

\begin{tabular}{|c|c|c|}
\hline Produktivitas tanaman kakao & Frekuensi & Persentase \\
\hline Tidak produktif & 35 & 87,5 \\
\hline Masih produtif & 5 & 12,5 \\
\hline Jumlah & $\mathbf{4 0}$ & $\mathbf{1 0 0}$ \\
\hline
\end{tabular}

Sumber : Data Primer 2011

Berdasarkan Tabel 19 diatas menunjukkan bahwa sebanyak 87,5\% responden menjawab bahwa tanaman kakao mereka tidak produktif lagi.

2) Hama Penyakit Menjadi Hambatan dalam Usaha tani Kakao Jenis hama penyakit yang menggangu untuk usahatani kakao dapat dilihat pada Tabel 20 berikut ini:

Tabel 20. Jenis hama penyakit yang menggangu tanaman kakao di Desa Banjarharjo

\begin{tabular}{|c|c|c|}
\hline Jenis hama penyakit & Frekuensi & Persentase \\
\hline Tupai & 3 & 7,5 \\
\hline Ulat & 1 & 2,5 \\
\hline Jamur & 1 & 2,5 \\
\hline $\begin{array}{c}\text { Penyakit busuk buah } \\
\text { (lalat buah) }\end{array}$ & 9 & 22,5 \\
\hline Tupai+Ulat & 2 & 5 \\
\hline $\begin{array}{c}\text { Tupai+Jamur } \\
\text { buai+Penyakit Busuk (lalat buah) }\end{array}$ & 1 & 2,5 \\
\hline Jumlah & $\mathbf{4 0}$ & $\mathbf{1 0 0}$ \\
\hline
\end{tabular}

Sumber : Data Primer 2011

Berdasarkan Tabel 20 diatas dapat diketahui bahwa 57,5\% dari jumlah responden menyatakan bahwa tanaman kakaonya banyak diserang tupai serta penyakit busuk buah yang disebabkan oleh lalat buah.

3) Hambatan Modal 
Hambatan modal usaha tani kakao dapat dilihat pada Tabel 21 berikut ini:

Tabel 21. Hambatan Modal

\begin{tabular}{|c|c|c|}
\hline Hambatan Modal & Frekuensi & Persentase \\
\hline Menjadi Hambatan & 9 & 22,5 \\
\hline $\begin{array}{c}\text { Tidak Menjadi } \\
\text { Hambatan }\end{array}$ & 31 & 77,5 \\
\hline Jumlah & $\mathbf{4 0}$ & $\mathbf{1 0 0}$ \\
\hline
\end{tabular}

Sumber : Data Primer 2011

Berdasarkan Tabel 21 diatas sebanyak $22,5 \%$ petani menjawab bahwa modal menjadi kendala dalam usahatani kakao karena petani masih mengharapkan bantuan pemerintah dalam pemeliharaan tanaman kakao terutama untuk pemberantasan hama dan persiapan lahan.

4) Hambatan Keterbatasan Waktu Pengelolaan

Hambatan keterbatasan waktu pengelolaan tanaman kakao dapat dilihat pada Tabel 22 berikut ini:

Tabel 22. Hambatan keterbatasan waktu pengelolaan

\begin{tabular}{|c|c|c|}
\hline Hambatan waktu & Frekuensi & Persentase \\
\hline Terhambat & 7 & 17,5 \\
\hline Tidak Menjadi Hambatan & 33 & 82,5 \\
\hline Jumlah & $\mathbf{4 0}$ & $\mathbf{1 0 0}$ \\
\hline
\end{tabular}

Sumber : Data Primer 2011

Berdasarkan Tabel 22 diatas diketahui sebanyak 17,5\% responden merasa kesulitan dalam membagi waktu untuk mengelola kakao, hal ini di karenakan banyaknya masyarakat yang mempunyai pekerjaan lain.

5) Hambatan kekurangan air

Hambatan kekurangan air di Desa banjarhajo dapat dilihat pada tabel berikut 23 ini:

Tabel 23. Hambatan kekurangan air di Desa Banjarharjo

\begin{tabular}{|c|c|c|}
\hline Hambatan kekurangan air & Frekuensi & Persentase \\
\hline Terhambat & 21 & 52,5 \\
\hline Tidak Menjadi Hambatan & 19 & 47,5 \\
\hline Jumlah & $\mathbf{4 0}$ & $\mathbf{1 0 0}$ \\
\hline
\end{tabular}

Sumber : Data Primer 2011

Berdasarkan Tabel 23 diatas dapat dilihat bahwa sebagian besar masyarakat yaitu sebanyak $52,5 \%$ merasa terhambat dengan adanya musim kemarau berkepanjangan karena persediaan air tanah berkurang sehingga akan menggangu kesuburan tanaman kakao.

d. Cara menggatasi masalah dalam pengelolaan tanaman kakao

Cara menggatasi masalah dalam pengelolaan tanaman kakao di Desa Banjarharjo dapat dilihat pada Tabel 24 berikut ini: 
Tabel 24. Cara menggatasi masalah dalam pengelolaan tanaman kakao di Desa Banjarharjo

\begin{tabular}{|c|c|c|c|}
\hline No & Penangananan masalah & Frekuensi & Persentase \\
\hline 1 & Peremajaan tanaman & 6 & 15 \\
\hline 2 & $\begin{array}{c}\text { Menyemprot hama dengan } \\
\text { insektisida }\end{array}$ & 18 & 45 \\
\hline 3 & Meminjam modal di kas desa & 2 & 5 \\
\hline 4 & $\begin{array}{c}\text { Mengunakan jasa tenaga kerja } \\
\text { bayaran }\end{array}$ & 4 & 10 \\
\hline 5 & Pompanisasi & 10 & 25 \\
\hline & Jumlah & $\mathbf{4 0}$ & $\mathbf{1 0 0}$ \\
\hline
\end{tabular}

Sumber : Data Primer 2011

e. Usaha peningkatan produktivitas tanaman kakao di Desa Banjarharjo

1) Usaha Teknis

Usaha teknis merupakan upaya yang dilakukan oleh masyarakat secara langsung ke lapangan. Berdasarkan penyuluhan yang telah dilakukan oleh Dinas Kehutanan dan Perkebunan Propinsi DIY tanggal 2 November 2011 Upaya teknis yang dilakukan dalam peningkatan produktivitas tanaman kakao meliputi:
a) Pemilihan Bibit Unggul
b) Sanitasi
c) Pemetikan Rutin
d) Sambung Samping
e) Sarungisasi kakao

2) Usaha Non Teknis

Usaha non teknis yaitu upaya yang dilakukan secara tidak langsung dilapangan berupa persiapan-persiapan untuk kemudian dapat dipraktekan langsung ke lapangan. Usaha non teknis dalam peningkatan produktivitas tanaman kakao antara lain;

a) Mengikuti penyuluhan

Petani mengikuti penyuluhan yang dilakukan oleh dinas perkebunan setiap 3 bulan sekali.

b) Kelompok Tani

Perkumpulan tani yang ada di Desa Banjarharjo salah satunya dari Dusun Padakan Ngasem yang bernama "Kelapa Mas".

c) Membaca buku maupun informasi yang berkaitan dengan Usaha tani kakao

d) Masyarakat mencari informasi tentang usaha tani kakao dengan membaca buku, modul maupun informasi media masa. 


\section{Kesimpulan}

Berdasarkan penelitian yang telah dilaksanakan, maka dapat ditarik kesimpulan sebagai berikut:

1. Kondisi fisik dan non fisik yang mempengaruhi usaha tani kakao

a. Jika dilihat dari segi iklim, topografi dan tanah, kondisi fisik daerah penelitian sesuai untuk budidaya tanaman kakao.

b. Kondisi non fisik daerah penelitian yang berkaitan bagi usahatani kakao yaitu:

1) Modal

Modal bibit diperoleh dari pemerintah yaitu oleh PT Pagelaran

2) Tenaga kerja

Sebagian besar pengelolaan tanaman kakao dikerjakan sendiri.

3) Transportasi

Sebagian besar masyarakat hanya berjalan kaki dalam memasarkan hasil panen kakao karena jarak koperasi yang dekat.

4) Pemasaran

Pemasaran panen kakao sebagian besar dijual ke koperasi desa selain itu juga di pasar dan tengkulak dengan harga jual Rp.17.000- Rp.25.000/kg kering.

5) Fasilitas kredit

Petani kakao tidak menggunakan fasilitas kredit dari bank, namun beberapa menggunakan penjaman kas desa untuk biaya pengelolaan tanaman kakao.

6) Teknologi

Penggunaan teknologi dalam pengelolaan kakao masih manual tanpa mesin. Informasi tentang usaha tani diperoleh melalui penyuluhan dari pemerintah, KKN maupun media masa.

2. Faktor-faktor yang menyebabkan penurunan produktivitas tanaman kakao di Desa Banjarharjo.

a. Umur tanaman kakao sudah terlalu tua

b. Adanya hama dan penyakit tanaman kakao

c. Keterbatasan modal dalam pengelolaan tanaman kakao d) Kurangnya air pada saat musim kemarau

d. Keterbatasan waktu untuk mengelola tanaman kakao

3. Usaha peningkatan produktivitas tanaman kakao

a. Usaha Teknis
1) Pemilihan bibit Unggul
2) Sanitasi
3) Pemetikan rutin
4) Sambung samping
5) Sarungisasi Kakao

b. Usaha Non Teknis

1) Mengikuti penyuluhan

2) Kelompok Tani 
3) Membaca buku maupun informasi yang berkaitan dengan Usaha tani kakao

\section{Saran}

Berdasarkan kesimpulan tersebut diatas maka dapat diajukan saran- saran sebagai berikut:

1. Bagi pemerintah

a. Pemerintah diharapkan segera bertindak ketika ada permasalahan dalam pengolahan pertanian masyarakat, salah satunya tanaman kakao.

b. Pemerintah perlu memberikan penyuluhan-penyuluhan maupun pelatihan bagi masyarakat tentang pengelolaan usahatani kakao secara baik dan benar.

c. Pemerintah perlu mengadakan kerjasama dengan masyarakat terutama dalam upaya peningkatan nilai ekonomis tanaman kakao dengan meningkatkan mutu atau kualitas kakao.

2. Bagi petani kakao di Desa Banjarharjo

a. Petani harus lebih peka jika tanaman kakao sudah tidak produktiv lagi, supaya penanggananya lebih cepat dan masyarakat tidak mengalami gagal panen.

b. Dengan adanya usahatani kakao diharapkan masyarakat mampu belajar cara bercocok tanam tanaman kakao dengan baik.

c. Pihak pertanian diharapkan dapat memberikan sumbangan bagi pemerintah dalam sektor pendapatan devisa dari ekspor kakao dan dapat meningkatkan hasil produksi.

\section{Daftar Pustaka}

AAK. 2007. Dasar-Dasar Bercocok Tanam. Yogyakarta : Kanisius.

Abbas Tjaka Wiralaksana dan M. Cuhaya Soeriatatmadja. 1983. Usaha Tani. Jakarta: Depdikbud.

Abdoel Djamali. 2000. Manajemen Usaha Tani. Jakarta: Depdiknas. Ance Gunarsih Kartasapoetra. 2006. Klimatologi : Pengaruh Iklim Terhadap Tanah dan Tanaman. Jakarta: Bumi Aksara. 
Arikunto.Suharsimi. 2006. Prosedur penelitian Praktek. Jakarta : Rineka Cipta.

Benyamin Lakitan. 2004. Dasar-Dasar Klimatologi. Jakarta : Raja Grafindo Persada.

Dani Kurniawan. 2010. Skripsi Usahatani Bawang merah Di Desa Gadingharjo Ngargosari Kecamatan Sanden Kabupaten Bantul.Skripsi: FISE UNY.

Data Tanaman Kakao Desa Banjarharjo 2009.

Dinas Kehutanan dan Perkebunan Propinsi DIY.2008. Kardiyono.Maret2010. Tingkatkan Produktivitas Kakao dengan Teknologi Sambung Samping:Surat Kabar Berkah hal 16-22 edisi 257.

Monografi Desa Banjarharjo kecamatan kalibawang. 2010. BP3K Kalibawang.

Muljana Wahju. 2001. Bercocok Tanam Cokelat. Semarang: CV. Aneka Ilmu

Munier, FF., dkk. 2005.Ringkasan Laporan Hasil Pengkajian Pengembangan Sistem Usahatani Integrasi Kambing Kakao di Sulawesi Tengah.

Nursid sumaatmadja.1981. Studi Geografi Suatu Pendekatan dan Analisa Keruangan. Bandung: Alumni.

Prabundu Tika, Moh. 2005. Metode penelitian Geografi. Jakarta: Bumi Aksara.

Suharsimi Arikunto. 2006. Prosedur Penelitian Suatu Pendekatan Praktek.Jakarta : Rineka Cipta.

Sunanto Hatta. 1994. Cokelat. Yogyakarta: Kanisius.

Suripin.2004. Pelestarian Sumber Daya Tanah dan Air. Yogyakarta: Andi. Sutrisno Hadi.2004. Statistik 2.Yogyakarta : Andi Offset.

Veronica Reni Wijayanti. 2010. Usaha Tani Kakao dan Tingkat Ekonomi Petani di Desa Banjarasri Kecamatan kalibawang Kabupaten Kulonprogo. Skripi: FISE UNY.

Whynne Charles dan Hammond. 1985. Elements Of Human Geography. London: George Allen\&Unwin 